IZA DP No. 5975

Productivity Gains from R\&D Investment: Are High-Tech Sectors Still Ahead?

Raquel Ortega-Argilés

Mariacristina Piva

Marco Vivarelli

September 2011 


\title{
Productivity Gains from R\&D Investment: Are High-Tech Sectors Still Ahead?
}

\author{
Raquel Ortega-Argilés \\ IN+ Center, Instituto Superior Técnico, Lisboa \\ Mariacristina Piva \\ Università Cattolica del Sacro Cuore \\ Marco Vivarelli \\ Università Cattolica del Sacro Cuore, \\ SPRU, University of Sussex and IZA
}

Discussion Paper No. 5975
September 2011

IZA

P.O. Box 7240

53072 Bonn

Germany

Phone: +49-228-3894-0

Fax: +49-228-3894-180

E-mail: iza@iza.org

\begin{abstract}
Any opinions expressed here are those of the author(s) and not those of IZA. Research published in this series may include views on policy, but the institute itself takes no institutional policy positions.

The Institute for the Study of Labor (IZA) in Bonn is a local and virtual international research center and a place of communication between science, politics and business. IZA is an independent nonprofit organization supported by Deutsche Post Foundation. The center is associated with the University of Bonn and offers a stimulating research environment through its international network, workshops and conferences, data service, project support, research visits and doctoral program. IZA engages in (i) original and internationally competitive research in all fields of labor economics, (ii) development of policy concepts, and (iii) dissemination of research results and concepts to the interested public.
\end{abstract}

IZA Discussion Papers often represent preliminary work and are circulated to encourage discussion. Citation of such a paper should account for its provisional character. A revised version may be available directly from the author. 


\section{ABSTRACT \\ Productivity Gains from R\&D Investment: Are High-Tech Sectors Still Ahead?*}

The purpose of this study is to investigate the relationship between a firm's R\&D expenditures considered as an investment in knowledge, and its productivity, looking at sectoral peculiarities which may emerge; to this end, we use a large unique longitudinal database consisting of 1,809 US and European manufacturing and service firms over the period 1990-2008, for a total of 16,079 observations. Our main findings can be summarised as follows: knowledge stock has a significant positive impact on a firm's productivity, with an overall elasticity of about 0.10 ; this general result is largely consistent with findings presented in previous literature in terms of the sign, the significance and the estimated magnitude of the relevant coefficient. More interestingly, the coefficient turns out to be significantly larger in the service and high-tech sectors than in the non-high-tech manufacturing sectors. These outcomes suggest that firms in high-tech sectors are still ahead in terms of the impact on productivity of their R\&D investments; moreover, a shift in favour of the service sectors seems to emerge.

JEL Classification: O33, L25

Keywords: R\&D, productivity, knowledge stock, panel data

Corresponding author:

Raquel Ortega-Argilés

IN+ Center for Innovation, Technology and Policy Research

Instituto Superior Técnico (IST)

Av. Rovisco País

1049-001 Lisboa

Portugal

E-mail: raquel.ortega.argiles@ist.utl.pt

\footnotetext{
* Financial support and data provision from the "Corporate R\&D and Productivity: Econometric Tests Based on Microdata" JRC-IPTS project are gratefully acknowledged.
} 


\section{Introduction}

The scope of this paper is limited to the investigation of the link between R\&D and productivity, in order to see whether previous evidence supporting a positive and significant relationship between the two can be confirmed, and whether sectoral peculiarities emerge. Interest in the microeconomic impact of R\&D expenditures is nowadays quite widespread and previous literature on the subject is vast (see Section 2). However, being limited to the investigation of the R\&D-productivity link, this paper will not deal directly with the 'rate of return' on R\&D in terms of firms' eventual competitive advantage and output expansion. It is not within the aim and scope of this study to assess how much a dollar spent in R\&D would yield in terms of increasing sales or profits; we simply assess the significance and magnitude of the R\&D-productivity elasticity, making use of a unique and new large longitudinal firm-level dataset.

A more recent issue in current debate is the alleged advantage of low-tech sectors over high-tech in achieving productivity gains from R\&D investments. The argument here is that catching-up low-tech sectors invest less in R\&D but benefit from a 'latecomer advantage' (see Marsili, 2001; Mairesse and Mohnen, 2005; Von Tunzelmann and Acha, 2005). If such were the case, we would expect a weaker relationship between $R \& D$ and productivity growth in high-tech sectors in comparison with their low-tech counterparts. Actually, this hypothesis contrasts with previous empirical evidence (see next section). Therefore, the second purpose of this study is to investigate whether significant sectoral differences emerge in the extent of the contribution of R\&D investment to productivity gains ${ }^{1}$.

The principal novel aspects of this study are twofold. Firstly, we propose a sectoral breakdown, using firm-level micro data; this approach has very few antecedents (reviewed in the next section). Secondly, we use a large original longitudinal database comprising both manufacturing and service firms, while most previous literature has been limited to the manufacturing sectors.

The rest of the paper is organized as follows: Section 2 provides a concise survey of the previous literature, while in Section 3 the data used and the adopted methodology are discussed, Section 4 deals with the empirical results and Section 5 briefly concludes.

\footnotetext{
1 As well as investigating possible differences between high-tech and non-high-tech manufacturing sectors, attention will also be devoted to the link between R\&D and productivity within service sectors; in fact in recent years a vast amount of literature supports the view that non-manufacturing industries are also heavy users of knowledge inputs. Indeed, in the emerging knowledge economy, EU services represent around three-quarters of European total value added and this share is increasing, while the weight of manufacturing industry in the economy is shrinking and now accounts for less than one-fifth of total value added (Segarra-Blasco, 2010; Duchêne et al., 2010).
} 


\section{Previous literature}

As mentioned in the previous section, there is a well-established stream of literature analysing the impact of R\&D activities on productivity (for surveys of the earlier literature, see Mairesse and Sassenou, 1991; Griliches 1995 and 2000; Mairesse and Mohnen, 2001). From the seminal article by Griliches (1979) up to more recent contributions such as those by Klette and Kortum (2004), Janz et al. (2004), Lööf and Heshmati (2006) and Rogers (2006), previous empirical works have found a significant contribution by R\&D to enhancing a firm's productivity. The estimated overall average elasticities range from 0.05 to 0.25 , depending on the methods of measurement and the data used. Most of these studies focus either on cross-country analyses or on one specific sector, mainly dealing with high-tech sectors such as the pharmaceutical or ICT-related sectors.

In contrast, considerably less attention has been devoted to determining whether the productivity gains from $\mathrm{R} \& \mathrm{D}$ are different across industrial sectors. Indeed, technological opportunities and appropriability conditions are so different across sectors (see Freeman, 1982; Pavitt, 1984; Winter, 1984; Aghion and Howitt, 1996; Dosi, 1997; Greenhalgh et al., 2001; Malerba, 2004) as to suggest the possibility of substantial differences in the specific sectoral R\&Dproductivity links. In this context, this paper will try to address the following questions: are the productivity impacts of $R \& D$ investments equally significant across sectors? If this is the case, what are the differences in the magnitudes of these effects? Does the productivity of a firm in a high-tech sector benefit more from an increase in $R \& D$ than that of one in a low-tech sector, or vice versa? At the same time, given that $R \& D$ input is generally added to labour and capital inputs in a production function framework, distinguishing by sectors will also allow us to better understand the impact of physical capital on productivity and how this may differ across sectors.

Although it targets sectoral differences, this study will be based on firm-level data; to our knowledge, not many studies have investigated the relationship between R\&D and productivity on a sectoral basis and, of these, only a few have used micro data. Examples are Griliches and Mairesse (1982) and Cuneo and Mairesse (1983), who performed two comparable studies using micro-level data and making a distinction between firms belonging to science-related sectors and firms belonging to other sectors. They found that the impact of R\&D on productivity for scientific firms (elasticity equal to 0.20 ) was significantly greater than for other firms $(0.10)$.

In a more recent paper, Verspagen (1995) used OECD sectoral-level data on value added, employment, capital expenditures and $R \& D$ investment in a standard production function framework. The author singled out three macro sectors: high-tech, medium-tech and low-tech, 
according to the OECD classification (Hatzichronoglou 1997). The major finding of the study was that the impact of $R \& D$ was significant and positive only in high-tech sectors, while for medium and low-tech sectors no significant effects could be found.

Using the methodology set up by Hall and Mairesse (1995) and also adopted in this study, Harhoff (1998) studied the R\&D/productivity link using a slightly unbalanced panel of 443 German manufacturing firms over the period 1977-1989, and found a significant impact, ranging from a minimum of 0.068 to a maximum of 0.137 , according to the different specifications and the different econometric estimators adopted. Interestingly, the effect of R\&D capital was considerably higher for high-technology firms compared to the residual groups of enterprises. In particular, for the high-tech firms the R\&D elasticity always turned out to be highly significant and ranging from 0.125 and 0.176 , while for the remaining firms the R\&D elasticity was either not significant (although positive) or lower (ranging from 0.090 to 0.096), according to the different estimation techniques used.

Wakelin (2001) applied a Cobb-Douglas production function where productivity was regressed on R\&D expenditures, capital and labour using data on 170 UK quoted firms during the period 1988-1992. She found R\&D expenditure had a positive and significant role in influencing a firm's productivity growth; moreover, firms belonging to sectors defined as 'net users of innovations' turned out to experience a higher impact resulting from R\&D.

Rincon and Vecchi (2003) also used a Cobb-Douglas framework in dealing with micro-data extracted from the Compustat database over the time period 1991-2001. They found that R\&Dreporting firms were more productive than their non-R\&D-reporting counterparts throughout the entire time period. However, the positive impact of R\&D expenditures turned out to be statistically significant both in manufacturing and services in the US, but only in manufacturing in the main three European countries (Germany, France and the UK). Their estimated significant elasticities ranged from 0.15 to 0.20 .

Kwon and Inui (2003) analysed 3,830 Japanese firms with no less than 50 employees in the manufacturing sector over the period 1995-1998, also using the methodology set up by Hall and Mairesse (1995). Using different estimation techniques, they found a significant impact of R\&D on labour productivity, with high-tech firms systematically showing higher and more significant coefficients than medium and low-tech firms.

Tsai and Wang (2004) also applied a Cobb-Douglas production function to a stratified sample of 156 large firms quoted on the Taiwan Stock Exchange. Their estimates made use of a balanced panel over the seven-year period from 1994 to 2000. They found that R\&D investment had a significant and positive impact on the growth of a firm's productivity (with an elasticity equal 
to 0.18 ). When a distinction was made between high-tech and other firms, this impact was much greater for high-tech firms (0.3) than for other firms (0.07).

Using microdata from the UK-DTI R\&D Scoreboard over the period 2000-2005, OrtegaArgilés et al. (2010) looked at the top 577 EU R\&D investors and found that the R\&D-productivity coefficient increased monotonically moving from the low-tech to the medium-high and high-tech sectors, ranging from a minimum of $0.03 / 0.05$ to a maximum of $0.14 / 0.17$.

Turning our attention to services, previous literature on the link between R\&D and productivity is scarce, notwithstanding the increasing role of services in contributing to the aggregate productivity growth of the economies (see Timmer et al., 2010). For instance, SegarraBlasco (2010), following the Crepon et al. (1998) specification and using Community Innovation Survey (CIS) data over the period 2002-2004 in Catalonia, concludes that a considerable heterogeneity in firms' performance can be found when manufacturing and service industries are compared, while even greater differences appear when high- and low-tech manufacturing firms are compared $^{2}$. His results show that R\&D expenditures, outcomes of innovation, physical capital investment, market share and exports have positive effects on labour productivity in both manufacturing and services. In particular, $R \& D$ intensity turns out to have the largest impact on labour productivity in the high-tech industries and services (see also Segarra and Teruel, 2011).

Finally, Bogliacino and Pianta (2011), using manufacturing and service data obtained from the innovation surveys CIS2, CIS3 and CIS4 conducted in eight major European countries, found a significant impact of in-house R\&D expenditures on labour productivity growth only in the hightech manufacturing and service sectors ${ }^{3}$.

Overall, previous empirical evidence on the subject supports the hypothesis of a positive and significant impact of R\&D on productivity at country, sector and firm level. More specifically, those studies including cross-section sectoral breakdowns seem to suggest a greater impact of R\&D investments on firm productivity in the high-tech sectors than in the low-tech ones. These outcomes will be tested again through a panel analysis applied to the original dataset described in the next section.

\footnotetext{
${ }^{2}$ The focus of the work is the increasing role of the knowledge intensive service sectors in the Catalonian economy.

${ }^{3}$ In particular, the authors have extended the Pavitt (1984) taxonomy to services and have found a significant impact of R\&D expenditures on labour productivity only in the extended 'Science-Based' and 'Specialised Suppliers' categories, but not in the 'Scale Intensive' and 'Supplier Dominated' categories.
} 


\section{Data and methodology}

The microdata used in this study were provided by the JRC-IPTS (Joint Research CentreInstitute for Prospective Technological Studies) of the European Commission; the information provided only concerns publicly-traded companies and is extracted from a variety of sources, including companies' annual reports, Securities and Exchange Commission (SEC) 10-K and 10-Q reports, daily news services and direct company contacts, using standardized data definitions and collection procedures to assure consistency in the data ${ }^{4}$.

Available data includes:

- Company identification, name and address, industry sector (Global Industry Classification Standard (GICS) that can be translated into the standard SIC classification);

- Fundamental financial data including income statements, cash flows, taxes, dividends and earnings, pension funds, property assets, ownership data, etc.

- Fundamental economic data, including the crucial information for this study, namely: sales, cost of goods (the difference between the former and the latter allows us to obtain value added), capital formation, R\&D expenditures, and employment.

Given the crucial role assumed by the R\&D variable in this study, it is worthwhile discussing in detail what is intended by R\&D in our database. This item represents all costs incurred during the year that relate to the development of new products and services. It is important to note that this amount is only the company's contribution and excludes amortization and depreciation of previous investments, so being a genuine flow of current in-house R\&D expenditures ${ }^{5}$. On the whole, the adopted definition of $R \& D$ is quite restrictive and refers to the genuine flow of current additional resources coming from internal sources and devoted to the launch and development of entirely new products.

The period covered is 1990-2008; however, the number of years available for each company depends upon the company's history; therefore, the data source is unbalanced in nature and comprises 1,809 companies (1,170 US firms and 639 European firms) for a total of 16,079 observations. Once we had acquired the rough original data from IPTS, we proceeded to construct a longitudinal database that would be adequate for running panel estimations to test the hypotheses

\footnotetext{
${ }^{4}$ The original data source is the Compustat Global dataset provided by Standard\&Poor's.

${ }^{5}$ In particular, the figure excludes: customer or government-sponsored R\&D expenditures; engineering expenses such as routinised ongoing engineering efforts to define, enrich or improve the qualities and characteristics of the existing products; inventory royalties; market research and testing.
} 
discussed in the previous section. Below we describe in detail the procedure we adopted to construct the dataset; for the sake of simplicity we proceed by steps.

\section{First step: data extraction}

In guiding the extraction of the data from the original JRC-IPTS database, the following criteria were adopted:

- select only those companies with $R \& D>0$ in at least one year of the available time span;

- $\quad$ select only those companies located in the US and in the EU 27 countries ${ }^{6}$;

- extract information concerning R\&D, sales, cost of goods (the difference between sales and cost of goods gives value added), capital formation, R\&D expenditures, and employment ${ }^{7}$.

All the value data were expressed in the current national currency in millions (for instance countries which currently use the euro have values in euros for the entire examined period).

\section{$\underline{\text { Second step: deflation of current nominal values }}$}

Nominal values were translated into constant price values through GDP deflators (source: IMF) centred on the year $2000^{8}$.

\section{Third step: values in PPP dollars}

Once we had obtained constant 2000 price values, all figures were converted into US dollars using the PPP exchange rate at year 2000 (source: OECD) ${ }^{9}$.

\footnotetext{
${ }^{6}$ While the original database also includes some Japanese and other Asian firms, these are latecomers only included in recent years and characterised by a lower level of reliability.

${ }^{7}$ More specifically, the available information for each firm included in the obtained workable dataset is as follows: 1) country of incorporation (location of the headquarters); 2) industry code at 2008; 3) R\&D expenses; 4) capital expenditures; 5) net turnover; 6) cost of goods sold; 7) employees.

${ }^{8}$ For a tiny minority of firms reporting in currencies other than the national one (i.e. 41 British, 9 Dutch, 4 Irish, 2 Luxembourg, 1 German and 1 Swedish firms reporting in US dollars; 7 British, 2 Danish and 1 Estonian firms reporting in euros), we decided to deflate the nominal values through the national GDP deflator as well.

${ }^{9}$ This procedure is consistent with that suggested by the Frascati Manual (OECD, 2002) in order to adjust R\&D expenditures correctly for differences in price levels over time (i.e. intertemporal differences requiring deflation) and between countries (i.e. interspatial differences requiring a PPP equivalent). In particular “...the Manual recommends the use of the implicit gross domestic product (GDP) deflator and GDP-PPP (purchasing power parity for GDP), which provide an approximate measure of the average real "opportunity cost" of carrying out the R\&D." (ibidem, page 217 ). 9 companies from 4 countries (Lithuania, Latvia, Malta and Romania) were excluded, due to the unavailability of PPP exchange rates from the OECD. Another 10 companies reporting in euros but located in non-euro countries (Denmark, Estonia and the UK) were excluded as well; finally, 58 European companies reporting in US dollars were kept as such.
} 
Fourth step: the format of the final data string

The obtained unbalanced database comprises 2,777 companies, over a period of 19 years (1990-2008).

Since one of the purposes of this study is to distinguish between high-tech and medium/lowtech sectors, we labelled as High-tech the following sectors ${ }^{10}$ :

- SIC 283: Drugs (ISIC Rev.3, 2423: Pharmaceuticals);

- SIC 357: Computer and office equipments (ISIC Rev.3, 30: Office, accounting and computing machinery);

- SIC 36 (excluding 366): Electronic and other electrical equipment and components, except computer equipment (ISIC Rev.3, 31: Electrical machinery and apparatus);

- SIC 366: Communication equipment (ISIC Rev.3, 32: Radio, TV and communications equipment);

- SIC 372-376: aircraft and spacecraft (ISIC Rev.3, 353: Aircraft and spacecraft);

- SIC 38: measuring, analyzing and controlling instruments (ISIC Rev.3, 33: Medical, precision and optical instruments)

Fifth step: computation of the R\&D and capital stocks.

As is common practice in this type of literature (see Jorgenson, 1990; Hulten, 1990; Hall and Mairesse, 1995; Griliches, 2000; Bönte, 2003; Parisi et al., 2006), stock indicators (rather than flows) were inserted as impact variables in the econometric specification introduced below. Indeed, as extensively discussed in the benchmark literature (see the contributions discussed in Section 2), a firm's productivity is affected by the cumulated stocks of capital and R\&D expenditures and not only by current or lagged flows. Within this framework, knowledge and physical capital stocks were computed using the perpetual inventory method. In practice, the following two formulas were applied:

(1) $\quad K_{t 0}=\frac{R \& D_{t 0}}{(g+\delta)}$ and $K_{t}=K_{t-1} \cdot(1-\delta)+R \& D_{t}$

where $R \& D=R \& D$ expenditures

(2) $\quad C_{t 0}=\frac{I_{t 0}}{(g+\delta)}$ and $C_{t}=C_{t-1} \cdot(1-\delta)+I_{t}$

where $\mathrm{I}=$ gross investment

\footnotetext{
${ }^{10}$ The standard OECD classification was taken as a reference (see Hatzichronoglou, 1997).
} 
where $g$ is generally computed as the ex ante pre-sample compounded average growth rate of the corresponding flow variable and $\delta$ is a depreciation rate.

However, our dataset spans 19 years and is unbalanced in nature. This means that only for a minority of firms information is available throughout the entire period, while many firms have information only for one or more spans over the 1990-2008 period, and these spans may be either very short or even isolated data. In addition, many firms display left-truncated data; for instance, some European firms have data only for the last decade. As a consequence, applying the formulas (1) and (2) strictly for computing initial stocks (for example using the first available three years to obtain the ex-ante growth rates) would have implied the loss of a huge amount of information ${ }^{11}$. In order to avoid this loss of much of the available data, we adopted the following criteria. First, it was decided to compute a rate of growth using the initial three years of a given spell and then apply it to the initial flow and not to the fourth year (i.e. our $t_{0}$ is the very first year of the spell and so $\mathrm{g}$ is an 'ex post' 3-year compound growth rate). Second, we applied this methodology iteratively to all the available spans of data comprising at least three consecutive years ${ }^{12}$. The combination of these two choices allowed us to keep all the available information, except for isolated data or pairs of data ${ }^{13}$.

As a result, when computing $R \& D$ and capital stocks according to the procedure described above, only R\&D and capital expenditure flow data with at least 3 observations in consecutive years were retained. This meant that 354 companies (mainly European) had to be dropped because they lacked 3 R\&D observations in successive years, while a further 30 companies lacked 3 capital expenditure observations in successive years. Thus, a total of 2,393 firms were retained at the end of this stage of the cleaning process.

Turning our attention to the depreciation rates $(\delta)$, we differentiated both between R\&D and capital and between the high-tech sectors vs. the other sectors, bearing in mind a common

\footnotetext{
${ }^{11}$ In the best case, say a firm with a complete set of 19 data over the period, this methodology would have implied the loss of 3 observations out of 19; in the worst case, say a firm characterized by data available only for some spells of three years each, this computation would have implied the loss of all the available information for that particular firm.

${ }^{12}$ This means that for firms characterised by breaks in the data we computed different initial stocks, one for each available time span, consistent with Hall (2007); however, differently from Hall (2007), we consider the different spans as belonging to the same firm and so we assign a single fixed or random effect to all of the spans belonging to the same company in the following econometric estimates.

${ }^{13}$ Although departing from the usual procedure, relying on ex-post growth rates appears acceptable in order to save most of the available information in the dataset; however, the impact of this choice on the values assumed by the stocks is limited, since they are also affected by the flow values and the depreciation rates. Finally, the chosen growth rate affects the initial stock and its impact quickly smoothes out as we move away from the starting year. Options for the choice of $g$ other than the standard one have been implemented by other authors as well. For instance, Parisi et al. (2006) assume that the rate of growth in R\&D investment at the firm level in the years before the first positive observation equals the average growth rate of industry R\&D between 1980 and 1991 (the time-span antecedent to the longitudinal micro-data used in their econometric estimates). In general terms, the choice of a feasible $g$ does not significantly affect the final econometric results of the studies. As clearly stated by Hall and Mairesse (1995, p.270, footnote 9): "In any case, the precise choice of growth rate affects only the initial stock, and declines in importance as time passes...".
} 
assumption in the reference literature, which uses $\delta=6 \%$ for computing the capital stock and $\delta=$ $15 \%$ for computing the R\&D stock (see Nadiri and Prucha, 1996 for the capital stock; Hall and Mairesse, 1995 and Hall, 2007 for the R\&D stock). Indeed, depreciation rates for the R\&D stocks have to be assumed to be higher than the corresponding rates for physical capital, since technological obsolescence is more rapid than the scrapping of physical capital. However, depreciation rates for the high-tech sectors have to be assumed to be higher than the corresponding rates for medium and low-tech sectors under the assumption that technological obsolescence - both related to R\&D efforts and to the embodied technologies incorporated in physical capital - is faster in the high-tech sectors. Specifically, depreciation rates were assumed to be equal to $6 \%$ and $7 \%$ with regard to physical capital in the low-medium and high-tech sectors respectively, while the corresponding $\delta$ for R\&D stocks were assumed equal to $15 \%$ and $18 \%$ respectively.

Once computed according to the formulas (1) and (2) and the adopted $g$ and $\delta$ rates, the resulting stocks were checked and negative ones were dropped ${ }^{14}$. Moreover, we excluded unreliable data such as those indicating negative sales and cost of goods equal to zero. After this further cleaning, we ended up with 1,884 companies.

\section{Sixth step: outliers.}

At this point, in order to check for the presence of outliers ${ }^{15}$, the Grubbs test (Grubbs, 1969) ${ }^{16}$ was run on the two critical variables in the analysis: the R\&D stock $(K)$ and the physical capital stock (C). Since the outlier test has to be applied to the variables used in the regression analysis, the test was run on the two normalised stock variables: $\mathrm{K} / \mathrm{E}$ and $\mathrm{C} / \mathrm{E}$ (see eq. 5). The Grubbs test is defined under the null hypothesis $\left(\mathrm{H}_{0}\right)$ that there are no outliers in the dataset; the test statistic is:

(3)

$$
\boldsymbol{G}=\frac{\max _{\boldsymbol{i}=1, . ., N}\left|\boldsymbol{Y}_{\boldsymbol{i}}-\overline{\boldsymbol{Y}}\right|}{\boldsymbol{S}}
$$

\footnotetext{
${ }^{14}$ The occurrence of negative stocks happens when $g$ turns out to be negative and larger in absolute value than $\delta$.

15 i.e. observations that appear to deviate markedly in terms of standard deviations from the relevant mean, possibly implying a bias in the econometric estimates.

${ }^{16}$ Specifically, the Grubbs test - also known as the maximum normed residual test, (Grubbs, 1969; Stefansky, 1972) - is used to detect outliers in a dataset, either creating a new variable or dropping outliers from the data set. Technically, the Grubbs test detects one outlier for iteration: the outlier is expunged from the data set and the test is iterated until no outliers remain. The default number of iterations is 16,000 .
} 
with $\overline{\boldsymbol{Y}}$ and $s$ denoting the sample mean and standard deviation, respectively. Therefore the Grubbs test detects the largest absolute deviation from the sample mean in units of the sample standard deviation. With a two-sided test, the null hypothesis of no outliers is rejected if:

(4) $\quad G>\frac{(N-1)}{\sqrt{N}} \sqrt{\frac{t^{2}(\alpha /(2 N), N-2)}{N-2+t^{2}(\alpha /(2 N), N-2)}}$

with $\boldsymbol{t}^{2}{ }_{(\boldsymbol{\alpha} /(2 N), N-2)}$ denoting the critical value of the $t$-distribution with $(N-2)$ degrees of freedom and a significance level of $\alpha /(2 N)$. After running the Grubbs test, 426 observations turned out to be outliers for the $\mathrm{K} / \mathrm{E}$ variable and 613 for the $\mathrm{C} / \mathrm{E}$ variable ( 54 outliers turned out to be common to both the variables). Therefore at the end of the process we ended up with a final dataset comprising 1,809 companies (1,170 US and $639 \mathrm{EU}$, for a total of 16,079 observations). Table 1 reports the distribution of the retained firms and observations across countries.

\section{$<$ INSERT TABLE $1>$}

Turning our attention to the econometric analysis, we started from the following specification, obtainable from a standard production function (see Griliches, 1986; Lichtenberg and Siegel, 1989; Hall and Mairesse, 1995; Verspagen, 1995).

(5) $\ln (\boldsymbol{V A} / \boldsymbol{E})_{i, t}=\alpha+\boldsymbol{\beta} \ln (\boldsymbol{K} / \boldsymbol{E})_{i, t}+\gamma \ln (\boldsymbol{C} / \boldsymbol{E})_{i, t}+\lambda \ln (\boldsymbol{E})_{i, t}+\delta \boldsymbol{T}+\boldsymbol{\varphi} C+\boldsymbol{Q S}+\boldsymbol{\eta}_{\boldsymbol{i}}+\boldsymbol{v}_{\boldsymbol{i}, \boldsymbol{t}}$ with: $i=1 \ldots 1,809 ; \quad t=1990 \ldots .2008$

where $\eta$ is the idiosyncratic individual effect and $v$ the usual error term. In all the following estimates, time (T), country $(\mathrm{C})$ and two-digit sector dummies $(\mathrm{S})$ were implemented in order to take into account both common macroeconomic effects and sectoral peculiarities. Yearly, country and sectoral dummies turned out to be significant in both the aggregate and the sectoral estimates ${ }^{17}$.

In accordance with data availability, our proxy for a firm's productivity is labour productivity, our pivotal impact variable is the knowledge capital $(K)$ per employee, and our second impact variable is physical capital $(C)$ per employee. Taking per capita values is one way of taking into account a firm's size and is a standard procedure in the literature (see Hall and Mairesse, 1995,

\footnotetext{
${ }^{17}$ As far as the latter are concerned, this means that even within the sectoral subgroups, specific two-digit technological opportunities and appropriability conditions continue to play an important role.
} 
p. 269; Crépon et al., 1998, p.123; Harhoff, 1998, p. 35; Kwon and Inui, 2003, p. 5). In this setting, total employment $(E)$ is a control variable and $\lambda$ measures the scale elasticity (if greater than zero, it indicates increasing returns) ${ }^{18}$.

\section{$\underline{\text { 4. Results }}$}

Table 2 provides some descriptive statistics regarding the main variables in our study.

$<$ INSERT TABLE $2>$

As can be seen from Table 2, the highest average productivity values (measured as VA/E) are in service sectors and, within manufacturing, in high-tech sectors. As far as the knowledge stock per employee $(\mathrm{K} / \mathrm{E})$ is concerned, not surprisingly the leading position is taken by the high-tech manufacturing sectors, followed by the service sectors; other manufacturing sectors reveal instead a very low average value. However, other manufacturing sectors show the highest physical capital per employee $(\mathrm{C} / \mathrm{E})$, far larger than the remaining sectors. Finally, with respect to size (measured as number of employees, E), other manufacturing sectors are characterised by the largest companies.

\section{$<$ INSERT TABLE $3>$}

On the basis of the preliminary correlation exercise reported in Table 3 the knowledge capital (K/E) turns out to be the main driver of productivity, with a $\rho$ of 0.451 in the overall sample, and homogeneously larger than 0.4 in the four sectoral groups. However, productivity is also significantly correlated to physical capital, although with a lower $\rho$ ( 0.277 in the overall sample).

This initial evidence is confirmed by the econometric analysis reported in Table 4. Specification (5) was tested through pooled ordinary least squares (POLS), fixed (FE) and random

\footnotetext{
${ }^{18}$ More comprehensive studies based on different datasets such as the CIS (Community Innovation Survey) generally consider eq. 5 as one of the 3 -equation model where the determinants of productivity are studied together with a knowledge production function and a base equation modelling the decision to engage in R\&D activities or not (see Crépon et al., 1998). Unfortunately, our database includes neither non-R\&D firms nor data on innovative output and this does not permit a simultaneous system approach.
} 
effects (RE) models ${ }^{19}$. Although POLS estimates are reported in the tables for the sake of completeness, the following comments refer only to the outcomes from the more reliable FE and RE models, checking for individual firms' unobservables ${ }^{20}$.

As can be seen in the first panel of Table 4, related to the overall sample, the knowledge stock has a significant positive impact on a firm's productivity, with an overall elasticity of about $0.09 / 0.11$; this general result is largely consistent with the previous literature in terms of the sign, the significance and the estimated magnitude of the relevant coefficient ${ }^{21}$. However, physical capital turns out to show a similar elasticity, confirming the important role of 'embodied technological change, 22 in enhancing labour productivity. As far as the employment regressor is concerned, the investigated firms reveal decreasing returns with the (relatively) smaller firms showing higher productivity gains $^{23}$. Finally, diagnosis tests reveal the satisfactory fitness of the chosen models and the usefulness of including the time, sectoral and country sets of dummies ${ }^{24}$.

\section{$<$ INSERT TABLE $4>$}

In Table 4, a first sectoral comparison is carried out, comparing manufacturing and service sectors. As can be seen, services show higher impacts of both knowledge and physical capital, revealing a better capacity in achieving productivity gains from both tangible and intangible investments. Consistently with the few previous studies including service sectors discussed in Section 2, these results confirm the crucial role of services, in particular those which are knowledge intensive $\mathrm{e}^{25}$, in translating physical and knowledge investments into productivity gains (see Sirilli and Evangelista, 1998; OECD, 2004; Timmer et al., 2010).

Table 5 contrasts the high-tech manufacturing sectors (as defined in Section 3, step 4) with all the other manufacturing sectors. As can be seen, high-tech sectors are found to be more effective

\footnotetext{
${ }^{19}$ As expected, all the estimated specifications turned out to be affected by heteroskedasticity (White, 1980); hence, robust standard errors were used.

${ }^{20}$ Hausman tests (reported in the tables) are always supporting the FE estimations as the most reliable; however, FE and RE outcomes are very consistent across Tables 4 and 5.

${ }^{21}$ As mentioned at the beginning of Section 2, previous studies estimated average elasticities ranging from 0.05 to 0.25 .

${ }^{22}$ The embodied nature of technological progress and the effects related to its spread in the economy were originally discussed by Salter (1960); in particular, vintage capital models describe an endogenous process of innovation in which the replacement of old equipment is the main way by which firms update their own technologies (see Freeman et al., 1982; Freeman and Soete, 1987). On the crucial role played by embodied technological change in traditional sectors, see Santarelli and Sterlacchini (1990) and Conte and Vivarelli (2005).

${ }^{23}$ It has to be noted that this is not an argument in favour of the role of R\&D in SMEs, since our sample is made up only of large firms.

${ }^{24}$ The estimates of the single dummies are not displayed in the tables but are available upon request.

${ }^{25}$ Unfortunately, paucity of data prevents us from conducting a separate empirical analysis for the knowledge intensive sectors.
} 
in achieving productivity gains from both knowledge and physical capital stock. This outcome is consistent with the previous literature discussed in Section 2 and supports a view stressing that R\&D investments still have a greater impact on firm productivity in the high-tech sectors than in the low-tech ones ${ }^{26}$.

$<$ INSERT TABLE 5 >

\section{Conclusions}

Although the positive and significant relationship between $R \& D$ and productivity has been proved by a long-established stream of literature, very few studies have provided empirical evidence about possible sectoral differences in the productivity gains obtainable from $R \& D$ activities. In order to fill this gap, in this research we conducted a microeconometric panel analysis of the effect of R\&D expenditures on firms' productivity using a unique large longitudinal database comprising US and European R\&D investors in both the manufacturing and service sectors. Our main findings can be summarised along the following lines.

Firstly, the positive link between R\&D and productivity is fully confirmed; in particular, our results are largely consistent with the previous literature in terms of the sign, the significance and the estimated magnitude of the relevant coefficient.

Secondly, service firms appear to be characterised by a higher impact of both R\&D and capital investment on labour productivity; this is an interesting result that would deserve further investigation.

Thirdly, manufacturing firms in high-tech sectors achieve more in terms of productivity gains connected with research activities in comparison with their low-tech counterparts. Therefore, consistently with previous literature, our results show that manufacturing firms in high-tech sectors are still far ahead in terms of the productivity impact of their research activities. Interestingly enough, high-tech manufacturing firms also reveal an advantage in achieving productivity gains from investment in physical capital.

The approach put forward in this paper could be further extended by future research through the use of different datasets, the split of the high-tech vs non-high-tech services and the consideration of additional innovation variables other than $R \& D$ expenditures.

\footnotetext{
${ }^{26}$ This outcome is in contrast with the hypothesis of the 'latecomer advantage' mentioned in the Introduction.
} 


\section{$\underline{\text { References }}$}

Aghion, P. and P. Howitt. 1996. "The Observational Implications of Schumpeterian Growth Theory", Empirical Economics, 21: 13-25.

Bogliacino, F. and M. Pianta. 2011. "Engines of Growth. Innovation and Productivity in Industry Groups", Structural Change and Economic Dynamics, 22: 41-53.

Bönte, W. 2003. "R\&D and Productivity: Internal vs. External R\&D - Evidence from West German Manufacturing Industries", Economics of Innovation and New Technology, 12: 343-360.

Conte A. and M. Vivarelli. 2005. "One or Many Knowledge Production Functions? Mapping Innovative Activity Using Microdata", IZA Discussion Paper 1878, Institute for the Study of Labor, Bonn.

Crépon, B., E. Duguet and J. Mairesse. 1998. "Research, Innovation, and Productivity: an Econometric Analysis at Firm Level", Economics of Innovation and New Technology, 7: 115-158.

Cuneo, P. and J. Mairesse. 1983. "Productivity and R\&D at the Firm Level in French Manufacturing", NBER Working Paper 1068, National Bureau for Economic Research, Cambridge, MA.

Dosi, G. 1997. "Opportunities, Incentives and the Collective Patterns of Technological Change", Economic Journal, 107: 1530-1547.

Duchêne, V., E. Lykogianni and A. Verbeek. 2010. "R\&D in Services Industries and the EU-US R\&D Investment Gap", Science and Public Policy, 37: 443-453.

Freeman, C. 1982. "The Economics of Industrial Innovation", London: Pinter.

Freeman, C. and L. Soete. 1987. "Technical Change and Full Employment", Oxford: Basil Blackwell.

Freeman, C., J. Clark and L. Soete. 1982. "Unemployment and Technical Innovation", London: Pinter.

Greenhalgh, C., M. Longland and D. Bosworth. 2001. "Technology Activity and Employment in a Panel of UK firms", Scottish Journal of Political Economy, 48: 260-282.

Griliches, Z. 1979. "Issues in Assessing the Contribution of Research and Development to Productivity Growth", Bell Journal of Economics, 10: 92-116.

- 1995. "R\&D and Productivity: Econometric Results and Measurement Issues", in "Handbook of the Economics of Innovation and Technological Change" edited by P. Stoneman. Oxford: Blackwell Publishers Ltd., 52-89.

—. 2000. "R\&D, Education, and Productivity", Cambridge, MA: Harvard University Press. 
Griliches, Z. and J. Mairesse. 1982. "Comparing Productivity Growth: An Exploration of French and US Industrial and Firm Data", NBER Working Paper 961, National Bureau of Economic Research, Cambridge, MA.

Grubbs, F. 1969. "Procedures for Detecting Outlying Observations in Samples", Technometrics, 11: $1-21$.

Hall, B.H. 2007. "Measuring the Returns to R\&D: The Depreciation Problem", NBER Working Paper 13473, National Bureau of Economic Research, Cambridge, MA.

Hall, B.H. and J. Mairesse. 1995. "Exploring the Relationship between R\&D and Productivity in French Manufacturing Firms", Journal of Econometrics, 65: 263-293.

Harhoff, D. 1998. "R\&D and Productivity in German Manufacturing Firms", Economics of Innovation and New Technology, 6: 29-49.

Hatzichronoglou, T. 1997. "Revision of the High-technology Sector and Product Classification", OECD, Paris.

Hulten, C.R. 1990. "The Measurement of Capital", in "Fifty Years of Economic Management", edited by E.R. Berndt and J.E. Triplett. Chicago: University of Chicago Press, 119-152.

Janz, N., H. Lööf and B. Peters. 2004. "Firm Level Innovation and Productivity - Is there a Common Story across Countries?", Problems and Perspectives in Management, 2: 1-22.

Jorgenson, D.W. 1990. "Productivity and Economic Growth", in "Fifty Years of Economic Growth", edited by E.R. Berndt and J.E. Triplett. Chicago: Chicago University Press, 19-118.

Klette, J. and S. Kortum. 2004. "Innovating Firms and Aggregate Innovation", Journal of Political Economy, 112: 986-1018.

Kwon, H.U. and T. Inui. 2003. "R\&D and Productivity Growth in Japanese Manufacturing Firms", ESRI Discussion Paper Series No.44, Tokyo.

Lichtenberg, F.R. and D. Siegel. 1989. "The Impact of R\&D Investment on Productivity - New Evidence Using Linked R\&D-LRD Data", NBER Working Paper 2901, National Bureau for Economic Research, Cambridge, MA.

Lööf, H. and A. Heshmati. 2006. "On the Relation between Innovation and Performance: A Sensitivity Analysis", Economics of Innovation and New Technology, 15: 317-344.

Mairesse, J. and P. Mohnen. 2001. "To Be or not To Be Innovative: An Exercise in Measurement", NBER Working Paper 8644, National Bureau of Economic Research, Cambridge, MA.

-. 2005. "The Importance of R\&D for Innovation: A Reassessment Using French Survey Data", Journal of Technology Transfer, 30:183-197.

Mairesse, J. and M. Sassenou. 1991. "R\&D and Productivity: A Survey of Econometric Studies at the Firm Level", NBER Working Paper 3666, National Bureau for Economic Research, Cambridge, MA. 
Malerba, F. 2004. "Sectoral Systems of Innovation", Milano: Università Commerciale Luigi Bocconi.

Marsili, O. 2001. "The Anatomy and Evolution of Industries", Northampton, MA: Edward Elgar.

Nadiri, M.I. and I.R. Prucha. 1996. "Estimation of the Depreciation Rate of Physical and R\&D Capital in the U.S. Total Manufacturing Sector", Economic Inquiry, 34:43-56.

OECD. 2002. "Frascati Manual - Proposed Standard Practice for Surveys on Research and Experimental Development", OECD, Paris.

OECD. 2004. "Understanding Economic Growth", OECD, Paris.

Ortega-Argilés R., M. Piva, L. Potters and M. Vivarelli. 2010. "Is Corporate R\&D Investment in High-tech Sectors More Effective?", Contemporary Economic Policy, 28: 353-365.

Parisi, M., F. Schiantarelli, and A. Sembenelli. 2006. "Productivity, Innovation Creation and Absorption, and R\&D. Microevidence for Italy", European Economic Review, 8:733-751.

Pavitt, K. 1984. "Sectoral Patterns of Technical Change: Towards a Taxonomy and a Theory", Research Policy, 13:343-373.

Rincon, A. and M. Vecchi. 2003. "Productivity Performance at the Company Level", in "EU Productivity and Competitiveness: An Industry Perspective. Can Europe Resume the Catching-up Process?", edited by M. O'Mahony and B. van Ark, Luxembourg: European Commission, 169-208.

Rogers, M. 2006. "R\&D and Productivity in the UK: Evidence from Firm-level Data in the 1990s", Economics Series Working Papers 255, University of Oxford.

Salter, W.E.G. 1960. "Productivity and Technical Change", Cambridge: Cambridge University Press.

Santarelli, E. and A. Sterlacchini. 1990. "Innovation, Formal vs. Informal R\&D, and Firm Size: Some Evidence from Italian Manufacturing Firms", Small Business Economics, 2: 223-228.

Segarra-Blasco, A. 2010. "Innovation and Productivity in Manufacturing and Service Firms in Catalonia: A Regional Approach", Economics of Innovation and New Technology, 19:233-258.

Segarra-Blasco, A. and M. Teruel. 2011. "Productivity and R\&D Sources: Evidence for Catalan Firms", Economics of Innovation and New Technology, forthcoming.

Sirilli, G. and R. Evangelista. 1998. "Technological Innovation in Services and Manufacturing: Results from Italian Surveys", Research Policy, 27(9), 881-899.

Stefansky, W. 1972. "Rejecting Outliers in Factorial Designs", Technometrics, 14: 469-479.

Timmer, M.P., R. Inklaar, M. O’Mahony and B. van Ark. 2010. "Economic Growth in Europe. A Comparative Industry Perspective", Cambridge: Cambridge University Press.

Tsai, K.H. and J.C. Wang. 2004. "R\&D Productivity and the Spillover Effects of High-tech Industry on the Traditional Manufacturing Sector: The Case of Taiwan", World Economy, 27: 1555-1570. 
Verspagen, B. 1995. "R\&D and Productivity: A Broad Cross-Section Cross-Country Look", Journal of Productivity Analysis, 6: 117-135.

Von Tunzelmann, N. and V. Acha. 2005. "Innovation in "Low-Tech" Industries." in "The Oxford Handbook of Innovation", edited by J. Fagerberg, D. C. Mowery, and R. R. Nelson, New York: Oxford University Press, 407-432.

Wakelin, K. 2001. "Productivity Growth and R\&D Expenditure in UK Manufacturing Firms", Research Policy, 30: 1079-1090.

White, H. 1980. "A Heteroskedasticity-Consistent Covariance Matrix Estimator and a Direct Test for Heteroskedasticity", Econometrica, 48: 817-838.

Winter, S.G. 1984. "Schumpeterian Competition in Alternative Technological Regimes", Journal of Economic Behaviour and Organisation, 5: 287-320. 
Tab. 1: Distribution of firms and observations across countries in the final version of the dataset

\begin{tabular}{|c|c|c|}
\hline COUNTRY & FIRMS & OBSERVATIONS \\
\hline AUSTRIA & 16 & 51 \\
\hline BELGIUM & 20 & 82 \\
\hline CZECH REPUBLIC & 1 & 4 \\
\hline DENMARK & 21 & 152 \\
\hline ESTONIA & 1 & 3 \\
\hline FINLAND & 41 & 157 \\
\hline FRANCE & 54 & 279 \\
\hline GERMANY & 141 & 749 \\
\hline GREECE & 11 & 41 \\
\hline HUNGARY & 3 & 12 \\
\hline IRELAND & 8 & 55 \\
\hline ITALY & 5 & 19 \\
\hline LUXEMBOURG & 3 & 9 \\
\hline NETHERLANDS & 25 & 165 \\
\hline SLOVENIA & 1 & 4 \\
\hline SPAIN & 3 & 7 \\
\hline SWEDEN & 62 & 386 \\
\hline UNITED KINGDOM & 223 & 1,299 \\
\hline USA & 1,170 & 12,605 \\
\hline
\end{tabular}

Table 2: Descriptive statistics: Mean and Standard Deviation in brackets

\begin{tabular}{|c|c|c|c|c|c|}
\hline & $\begin{array}{c}\text { OVERALL } \\
\text { SAMPLE } \\
(\text { Obs = 16,079) }\end{array}$ & $\begin{array}{c}\text { MANUFACTURING } \\
\text { SECTORS } \\
(\text { Obs = 12,876) }\end{array}$ & $\begin{array}{c}\text { SERVICE } \\
\text { SECTORS } \\
(\text { Obs = 3,203) }\end{array}$ & $\begin{array}{c}\text { HIGH-TECH } \\
\text { MANUFACTURING } \\
(\text { Obs = 7,693) }\end{array}$ & $\begin{array}{c}\text { OTHER } \\
\text { MANUFACTURING } \\
\text { (Obs = 5,183) }\end{array}$ \\
\hline VA/E & 102.781 & 99.565 & 115.709 & 112.038 & 81.050 \\
& $(91.008)$ & $(92.914)$ & $(81.648)$ & $(108.275)$ & $(58.938)$ \\
\hline K/E & 86.076 & 82.470 & 100.574 & 110.748 & 40.497 \\
& $(105.899)$ & $(106.904)$ & $(100.478)$ & $(119.007)$ & $(66.507)$ \\
\hline C/E & 81.026 & 84.886 & 65.512 & 78.142 & 94.895 \\
& $(80.542)$ & $(81.585)$ & $(74.222)$ & $(76.709)$ & $(87.380)$ \\
\hline E & 11,204 & 11,951 & 8,199 & 8,179 & 17,551 \\
& $(35,302)$ & $(35,250)$ & $(35,356)$ & $(23,264)$ & $(47,237)$ \\
\hline
\end{tabular}


Table 3: Correlation matrices

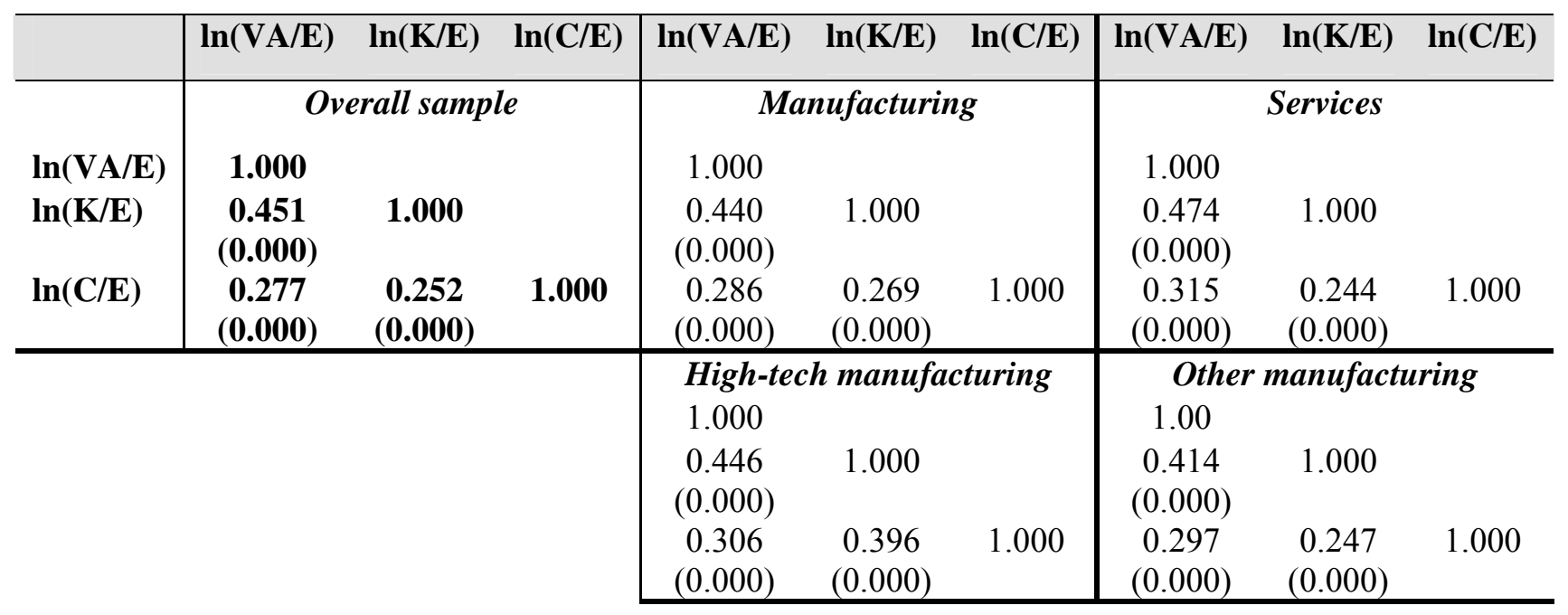

Note: p-values in parentheses 
Table 4: Sectoral decomposition: Manufacturing (High-tech + Other) and Service sectors

\begin{tabular}{|c|c|c|c|c|c|c|c|c|c|}
\hline & \multicolumn{3}{|c|}{ Whole sample } & \multicolumn{3}{|c|}{ Manufacturing } & \multicolumn{3}{|c|}{ Services } \\
\hline & POLS & FE & $\mathbf{R E}$ & POLS & $\mathbf{F E}$ & $\mathbf{R E}$ & POLS & FE & RE \\
\hline Log(R\&D stock per employee) & $\begin{array}{c}0.205 * * * \\
(0.006)\end{array}$ & $\begin{array}{c}0.089 * * * \\
(0.007)\end{array}$ & $\begin{array}{c}0.107 * * * \\
(0.007)\end{array}$ & $\begin{array}{c}0.209 * * * \\
(0.007)\end{array}$ & $\begin{array}{c}0.073 * * * \\
(0.008)\end{array}$ & $\begin{array}{c}0.095 * * * \\
(0.007)\end{array}$ & $\begin{array}{c}0.177 * * * \\
(0.014)\end{array}$ & $\begin{array}{c}0.114 * * * \\
(0.014)\end{array}$ & $\begin{array}{c}0.127 * * * \\
(0.011)\end{array}$ \\
\hline Log(Physical stock per employee) & $\begin{array}{c}0.115 * * * \\
(0.006)\end{array}$ & $\begin{array}{c}0.093 * * * \\
(0.006)\end{array}$ & $\begin{array}{c}0.099 * * * \\
(0.006)\end{array}$ & $\begin{array}{c}0.109 * * * \\
(0.007)\end{array}$ & $\begin{array}{c}0.086^{* * *} \\
(0.007)\end{array}$ & $\begin{array}{c}0.093 * * * \\
(0.006)\end{array}$ & $\begin{array}{c}0.148 * * * \\
(0.014)\end{array}$ & $\begin{array}{c}0.115^{* * *} \\
(0.014)\end{array}$ & $\begin{array}{c}0.125 * * * \\
(0.012)\end{array}$ \\
\hline Log(Employees) & $\begin{array}{c}0.031 * * * \\
(0.003)\end{array}$ & $\begin{array}{c}-0.049 * * * \\
(0.007)\end{array}$ & $\begin{array}{c}-0.012 * * \\
(0.007)\end{array}$ & $\begin{array}{c}0.025^{* * *} \\
(0.004)\end{array}$ & $\begin{array}{c}-0.078 * * * \\
(0.009)\end{array}$ & $\begin{array}{c}-0.029 * * * \\
(0.007)\end{array}$ & $\begin{array}{c}0.062 * * * \\
(0.009)\end{array}$ & $\begin{array}{c}0.021 \\
(0.014)\end{array}$ & $\begin{array}{c}0.033 * * * \\
(0.011)\end{array}$ \\
\hline Constant & $\begin{array}{l}0.860 * \\
(0.493) \\
\end{array}$ & $\begin{array}{c}3.529 * * * \\
(0.038)\end{array}$ & $\begin{array}{c}1.115 \\
(0.984) \\
\end{array}$ & $\begin{array}{c}2.957 * * * \\
(0.481)\end{array}$ & $\begin{array}{c}3.559 * * * \\
(0.036)\end{array}$ & $\begin{array}{c}1.655 \\
(1.023) \\
\end{array}$ & $\begin{array}{c}3.513 * * * \\
(0.164)\end{array}$ & $\begin{array}{c}3.744 * * * \\
(0.085)\end{array}$ & $\begin{array}{l}-0.164 \\
(0.975) \\
\end{array}$ \\
\hline $\begin{array}{l}\text { Wald time-dummies } \\
\text { (p-value) } \\
\text { Wald country-dummies } \\
\text { (p-value) } \\
\text { Wald sectoral-dummies } \\
\text { (p-value) }\end{array}$ & $\begin{array}{c}4.5 * * * \\
(0.000) \\
52.5 * * * \\
(0.000) \\
174.2 * * * \\
(0.000) \\
\end{array}$ & $\begin{array}{c}11.4 * * * \\
(0.000) \\
- \\
-\end{array}$ & $\begin{array}{c}165.4 * * * \\
(0.000) \\
67.2 * * * \\
(0.000) \\
233.1 * * * \\
(0.000) \\
\end{array}$ & $\begin{array}{l}4.3 * * * \\
(0.000) \\
72.8 * * * \\
(0.000) \\
69.9 * * * \\
(0.000) \\
\end{array}$ & $\begin{array}{c}15.2 * * * \\
(0.000) \\
- \\
-\end{array}$ & $\begin{array}{c}216.5 * * * \\
(0.000) \\
49.3 * * * \\
(0.000) \\
142.4 * * * \\
(0.000) \\
\end{array}$ & $\begin{array}{l}2.7 * * * \\
(0.000) \\
13.5 * * * \\
(0.000) \\
94.8 * * * \\
(0.000) \\
\end{array}$ & $\begin{array}{c}3.1 * * * \\
(0.000) \\
- \\
-\end{array}$ & $\begin{array}{l}61.0 * * * \\
(0.000) \\
30.7 * * * \\
(0.000) \\
88.6 * * * \\
(0.000) \\
\end{array}$ \\
\hline $\begin{array}{l}\text { Rsq (overall) } \\
\text { Rsq (between) } \\
\text { Rsq (within) } \\
\text { Hausman test (p-value) } \\
\text { Obs. } \\
\text { N. of firms }\end{array}$ & $\begin{array}{c}0.32 \\
- \\
-\end{array}$ & $\begin{array}{c}0.18 \\
0.09 \\
0.12 \\
155.01 \\
16,079 \\
1,809\end{array}$ & $\begin{array}{r}0.29 \\
0.24 \\
0.11 \\
0.000)\end{array}$ & $\begin{array}{c}0.31 \\
- \\
-\end{array}$ & $\begin{array}{c}0.13 \\
0.06 \\
0.10 \\
45.89 \\
12,876 \\
1,383\end{array}$ & $\begin{array}{r}0.26 \\
0.22 \\
0.10 \\
0.000)\end{array}$ & 0.39 & $\begin{array}{l}0.28 \\
0.29 \\
0.13 \\
19.29(0 \\
3,203 \\
426\end{array}$ & $\begin{array}{l}0.37 \\
0.45 \\
0.13 \\
.000)\end{array}$ \\
\hline
\end{tabular}

Notes: - (Robust in POLS) standard-errors in parentheses; ${ }^{*}$ significance at $10 \%,{ }^{* *} 5 \%, * * * 1 \%$.

- For time dummies, country dummies and sectoral dummies, Wald tests of joint significance are reported.

\# The Hausman statistic results correspond to the model specification without dummy sets. 
Table 5: Sectoral decomposition: High-tech and Other manufacturing sectors

\begin{tabular}{|c|c|c|c|c|c|c|c|c|c|}
\hline & \multicolumn{3}{|c|}{ Manufacturing } & \multicolumn{3}{|c|}{ High-tech manufacturing } & \multicolumn{3}{|c|}{ Other manufacturing } \\
\hline & POLS & FE & RE & POLS & FE & RE & POLS & FE & RE \\
\hline Log(R\&D stock per employee) & $\begin{array}{c}0.209 * * * \\
(0.007)\end{array}$ & $\begin{array}{c}0.073 * * * \\
(0.008)\end{array}$ & $\begin{array}{c}0.095 * * * \\
(0.007)\end{array}$ & $\begin{array}{c}0.236 * * * \\
(0.011)\end{array}$ & $\begin{array}{c}0.070 * * * \\
(0.012)\end{array}$ & $\begin{array}{c}0.098 * * * \\
(0.010)\end{array}$ & $\begin{array}{c}0.159 * * * \\
(0.008)\end{array}$ & $\begin{array}{c}0.053 * * * \\
(0.009)\end{array}$ & $\begin{array}{c}0.071 * * * \\
(0.008)\end{array}$ \\
\hline Log(Physical stock per employee) & $\begin{array}{c}0.109 * * * \\
(0.007)\end{array}$ & $\begin{array}{c}0.086 * * * \\
(0.007)\end{array}$ & $\begin{array}{c}0.093 * * * \\
(0.006)\end{array}$ & $\begin{array}{c}0.117 * * * \\
(0.011)\end{array}$ & $\begin{array}{c}0.092 * * * \\
(0.010)\end{array}$ & $\begin{array}{c}0.100 * * * \\
(0.009)\end{array}$ & $\begin{array}{c}0.093 * * * \\
(0.008)\end{array}$ & $\begin{array}{c}0.070 * * * \\
(0.008)\end{array}$ & $\begin{array}{c}0.078 * * * \\
(0.007)\end{array}$ \\
\hline Log(Employees) & $\begin{array}{c}0.025^{* * *} \\
(0.004)\end{array}$ & $\begin{array}{c}-0.078 * * * \\
(0.009)\end{array}$ & $\begin{array}{c}-0.029 * * * \\
(0.007)\end{array}$ & $\begin{array}{c}0.042 * * * \\
(0.005)\end{array}$ & $\begin{array}{c}-0.086^{* * *} \\
(0.012)\end{array}$ & $\begin{array}{c}-0.028 * * * \\
(0.009)\end{array}$ & $\begin{array}{c}-0.010^{*} \\
(0.006)\end{array}$ & $\begin{array}{c}-0.107 * * * \\
(0.013)\end{array}$ & $\begin{array}{c}-0.054 * * * \\
(0.009)\end{array}$ \\
\hline Constant & $\begin{array}{c}2.957 * * * \\
(0.481)\end{array}$ & $\begin{array}{c}3.559 * * * \\
(0.036)\end{array}$ & $\begin{array}{c}1.655 \\
(1.023)\end{array}$ & $\begin{array}{c}2.840 * * * \\
(0.493)\end{array}$ & $\begin{array}{c}3.514 * * * \\
(0.051)\end{array}$ & $\begin{array}{c}2.465 * * * \\
(0.831)\end{array}$ & $\begin{array}{c}3.144 * * * \\
(0.457)\end{array}$ & $\begin{array}{c}3.758 * * * \\
(0.049)\end{array}$ & $\begin{array}{r}1.286^{*} \\
(0.761)\end{array}$ \\
\hline $\begin{array}{l}\text { Wald time-dummies } \\
\text { (p-value) } \\
\text { Wald country-dummies } \\
\text { (p-value) } \\
\text { Wald sectoral-dummies } \\
\text { (p-value) }\end{array}$ & $\begin{array}{l}4.3 * * * \\
(0.000) \\
72.8 * * * \\
(0.000) \\
69.9 * * * \\
(0.000) \\
\end{array}$ & $\begin{array}{c}15.2 * * * \\
(0.000) \\
- \\
-\end{array}$ & $\begin{array}{c}216.5 * * * \\
(0.000) \\
49.3 * * * \\
(0.000) \\
142.4^{* * *} \\
(0.000) \\
\end{array}$ & $\begin{array}{l}2.2 * * * \\
(0.002) \\
11.3 * * * \\
(0.000) \\
92.3 * * * \\
(0.000) \\
\end{array}$ & $\begin{array}{c}10.2^{* * *} \\
(0.000) \\
- \\
-\end{array}$ & $\begin{array}{c}165.4 * * * \\
(0.000) \\
67.2 * * * \\
(0.000) \\
233.1 * * * \\
(0.000) \\
\end{array}$ & $\begin{array}{l}2.5 * * * \\
(0.000) \\
74.7 * * * \\
(0.000) \\
67.1 * * * \\
(0.000) \\
\end{array}$ & $\begin{array}{c}9.0 * * * \\
(0.000) \\
- \\
-\end{array}$ & $\begin{array}{c}138.5 * * * \\
(0.000) \\
45.7 * * * \\
(0.000) \\
196.8 * * * \\
(0.000) \\
\end{array}$ \\
\hline $\begin{array}{l}\text { Rsq (overall) } \\
\text { Rsq (between) } \\
\text { Rsq (within) } \\
\text { Hausman (p-value) } \\
\text { Obs. } \\
\text { N. of firms }\end{array}$ & $\begin{array}{c}0.31 \\
- \\
-\end{array}$ & $\begin{array}{c}0.13 \\
0.06 \\
0.10 \\
45.89 \\
12,876 \\
1,383\end{array}$ & $\begin{array}{r}0.26 \\
0.22 \\
0.10 \\
0.000)\end{array}$ & 0.28 & $\begin{array}{l}0.10 \\
0.04 \\
0.11 \\
37.73 \\
7,693 \\
804\end{array}$ & $\begin{array}{r}0.22 \\
0.16 \\
0,11 \\
0.000)\end{array}$ & 0.40 & $\begin{array}{l}0.08 \\
0.03 \\
0.10 \\
28.68(() \\
5,183 \\
579\end{array}$ & $\begin{array}{r}0.36 \\
0.36 \\
0.10 \\
000)\end{array}$ \\
\hline
\end{tabular}

